\title{
PENGARUH GAYA KEPEMIMPINAN TERHADAP DISIPLIN KERJA PEGAWAI PADA KELURAHAN BALAI AGUNG KECAMATAN SEKAYU KABUPATEN MUSI BANYUASIN
}

\author{
Usailan Oemar \\ Sekolah Tinggi Ilmu Ekonomi Rahmaniyah
}

\begin{abstract}
ABSTRAK
Penelitian ini bertujuan untuk mendeskripsikan keterkaitan antara Gaya Kepemimpinan dan disiplin kerja. Penelitian ini menggunakan pendekatan kuantitatif dengan jenis penelitian korelasional dengan variabel bebas Gaya Kepemimpinan (X) dan variabel terikat Disiplin Kerja (Y). Populasi dalam penelitian ini berjumlah 45 responden dengan jumlah sampel 40 responden. Hasil penelitian yang dilakukan terhadap Variabel (X) dan Variabel (Y) menunjukkan bahwa terdapat pengaruh gaya kepemimpinan terhadap disiplin kerja. Hal ini dibuktikan dengan hasil analisis menggunakan regresi linier sederhana dengan hasil $\mathrm{Y}=\mathrm{a}+\mathrm{bx} \mathrm{Y}=8.542+0.734 \mathrm{X}$. Yang telah dilakukan menggunakan aplikasi SPSS 20.
\end{abstract}

Kata kunci: Gaya Kepemimpinan, Disiplin Kerja.

\subsection{Latar Belakang Masalah}

Setiap organisasi pemerintah dituntut untuk dapat mengoptimalkan sumber daya manusia yang dikelola. Pengelolaan sumber daya manusia tidak lepas dari faktor Pegawai yang diharapkan dapat berprestasi sebaik mungkin demi mencapai tujuan organisasi pemerintah. Pegawai merupakan asset utama organisasi dan mempunyai peran yang strategis di dalam organisasi yaitu sebagai pemikir, perencana, dan pengendalian aktivitas organisasi.

Peran sumber daya manusia dapat di manfaatkan semaksimal mungkin dengan melakukan cara-cara untuk menggerakan manusia mau bekerja dengan keahliannya secara maksimal. Sukses dan tidaknya suatu organisasi pemerintahan dalam mencapai tujuan tergantung pada kemampuan sumber daya manusia yang dimilikinya. Pembinaan disiplin merupakan tindakan manajemen untuk mendorong para anggota organisasi memenuhi berbagai ketentuan.

Disiplin kerja merupakan salah satu fungsi manejemen sumber daya manusia yang penting dan merupakan kunci terwujudnya tujuan, karena tanpa adanya disiplin kerja maka sulit mewujudkan tujuan yang maksimal (Sudarmayanti, 2010:221). Menurut Rivai disiplin kerja adalah suatu alat yang digunakan para manajer untuk berkomunikasi dengan karyawan agar mereka bersedia untuk mengubah suatu perilaku serta sebagai suatu upaya untuk meningkatkan kesadaran dan kesediaan seseorang mentaati semua peraturan organisasi pemerintah atau perusahaan dan norma-norma sosial yang berlaku (2010:825). Disiplin kerja selanjutnya dapat dilakukan dengan pemberian sanksi berupa hukuman dan teguran agar dapat menciptakan efek jera bagi pegawai dan tidak mengulangi perbuatan yang serupa di masa mendatang serta dapat bekerja lebih baik lagi (Iswara, 2013:25). Oleh karena itu disiplin kerja pegawai memiliki pengaruh yang sangat penting dalam mewujudkan kinerja yang efektif dari sumber daya manusia yang berkualitas.

Dalam hal ini disiplin kerja sangat diperlukan dalam setiap organisasi pemerintahan karena disiplin kerja adalah suatu bentuk pelatihan yang berusaha 
memperbaiki dan membentuk pengetahuan, sikap dan perilaku pegawai sehingga para pegawai secara sukarela berusaha bekerja secara kooperatif dengan para pegawai yang lain serta meningkatkan produktivitas yang dihasilkan oleh para pegawai. Kedisiplinan ini adalah bagian dari tujuan utama dalam rangka membangun kualitas kerja dengan adanya pegawai yang efektif dan efisien yang memiliki disiplin tinggi serta loyalitas pengabdian yang penuh dalam tugas dan tanggung jawabnya serta berorientasi pada kesejahteraan kepada masyarakat.

Pemimpin memiliki peranan yang sangat penting dalam mendisiplinkan sebuah lembaga atau organisasi. Pemimpin merupakan seseorang yang memiliki kemampuan untuk mempengaruhi orang lain agar dapat melakukan sesuatu hal yang sesuai dengan keinginannya dan sesuai dengan tujuan organisasi. Kepemimpinan bukan hanya diartikan untuk mempengaruhi seseorang untuk mencapai tujuan melainkan juga merupakan suatu proses memotivasi tingkah laku pegawai dalam upaya perbaikan kelompok serta disiplin kerja dari pegawai pemerintahan.

Pemimpin memerlukan sifat-sifat kepemimpinan untuk dapat memimpin sejumlah orang yang banyak dan memiliki pola pikir yang berbeda-beda, diantaranya kepemimpinan demokratik, kepemimpinan partisipatif, kepemimpinan otoriter dan kepemimpinan delegatif. Seperti fenomena yang terjadi di kantor Kelurahan Balai Agung untuk menciptakan suasana yang tertib dan disiplin di lingkungan kerja pegawai tidak hanya bisa dilakukan dengan menunjuk orang lain untuk mentranformasikan secara optimal sumber daya organisasi dan juga tidak bisa dilakukan dengan cara hanya pendekatan, memberi dorongan dan memberi penghargaan sebagai imbalan, melainkan juga harus dengan kepemimpinan yang absolut atau mutlak serta ancaman hukuman (kepemimpinan otoriter) agar setiap pegawai memiliki rasa takut dan dapat menurut dengan apa yang diperintahkan serta dikatakan pimpinannya.

Gaya kepemimpinan yang sesuai dengan keadaan pemerintahan dan keinginan Kelurahan akan mendorong dalam peningkatan kinerja pegawai dalam pencapaian sasaran dan tujuan pemerintahan. Dalam pelaksanaan kegiatannya para pemimpin mempunyai gaya tersendiri dalam proses untuk mempengaruhi dan mengarahkan pegawainya, sehingga diharapkan mau bersama-sama berusaha mencapai tujuan pemerintahan melalui pelaksanaan pekerjaan yang telah ditentukan. Karena permasalahan yang dihadapi organisasi bervariasi, maka para pemimpin dituntut untuk mampu menerapkan gaya kepemimpinan yang bervariasi pula sesuai dengan keadaan yang dihadapi.

Permasalahan disiplin kerja yang terjadi di Kelurahan Balai Agung dapat dilihat dari, banyaknya pegawai yang telat masuk kantor dan pulang lebih awal jika tidak ada pimpinan,Dalam hal pekerjaan pimpinan kurang memberi perhatian atau arahan kepada bawahannya sehingga banyak pekerjaan yang tidak tepat waktudan Pimpinan tidak bisa memberi contoh atau panutan kepada bawahannya,hal ini dapat dilihat dari pimpinan yang sering datang tidak tepat waktudan jarang berada di kantor.

Hasil pantauan penulis permasalahan ini dipicu oleh gaya kepemimpinan Lurah Balai Agung, dimana dalam melaksanakan tugasnya Lurah Balai Agung kurang memotivasi pegawainya, baik menekankan tentang pekerjaan bawahanya maupun tentang disiplin kerja. Selain itu, kepemimpinan Lurah Balai Agung kurang improvisasi dalam menerapkan disiplin kerja kepada pegawai atau bawahannya, seperti : 1. Kurang memberi masukan-masukan positif kepada pegawai 2. Kurang memberikan semangat kepada pegawai 3. Kurangmenghargai pendapat/masukan yang diberikan pegawai kepada atasan, 4. Kurang mencontohkan sikap disiplin dengan gaya kepemimpinan 
Lurah Balai Agung ini menyebabkan tingkat disiplin kerja pegawai juga menurun. Hal tersebut dapat dilihat dari banyaknya perangkat yang menyalahi aturan prosedur kerja sepertibanyaknya pegawai yang telat masuk kantor dan pimpinan tidak memberikan teguran atau sanksi yang tegas kepada pegawai, dalam hal pekerjaan pimpinan kurang memberi perhatian atau arahan kepada bawahannya sehingga banyak pekerjaan yang tidak tepat waktu, pimpinan tidak bisa memberi contoh atau panutan kepada bawahannya, hal ini dapat dilihat dari pimpinan yang sering datang tidak tepat waktudan jarang berada di kantor, hal tersebut membuat para bawahan terlihat santai karena kurang pengawasan dari pimpinan, dalam melayani masyarakat mereka bersikap kurang ramah terhadap masyarakat hal ini dikarenakan ketidak tegasan pimpinan dalam mengawasi bawahannya dimana ini bisa mempengaruhi ketidak nyamanan masyarakat. hal ini dikarenakan kurangnya perhatian khusus pimpinan terhadap pegawainya dan pimpinan tidak memberikan teguran atau sanksi yang tegas.

Berdasarkan latar belakang diatas peneliti tertarik untuk melakukan penelitian dengan judul: "PENGARUH GAYA KEPEMIMPINAN TERHADAP DISIPLIN KERJA PEGAWAI PADA KELURAHAN BALAI AGUNG KECAMATAN SEKAYU KABUPATEN MUSI BANYUASIN".

\subsection{Rumusan Masalah}

Berdasarkan latar belakang diatas penulis merumuskan masalah adakah Pengaruh Antara Gaya Kepemimpinan Terhadap Disiplin Kerja Pegawai Pada Kelurahan Balai Agung Kecamatan Sekayu Kabupaten Musi Banyuasin?

\subsection{Tujuan Penelitian}

Adapun yang menjadi tujuan penelitian ini adalah untuk mengetahui Pengaruh Antara Gaya Kepemimpinan Terhadap Disiplin Kerja Pegawai Pada Kelurahan Balai Agung Kecamatan Sekayu Kabupaten Musi Banyuasin.

\subsection{Lokasi dan Waktu Penelitian}

Lokasi penelitian di lakukan di Kelurahan Balai Agung Kabupaten Musi Banyuasin yang beralamatkan di Jalan Kolonel Wahid Udin Nomor. 009 RT. 032 RW. 10 LK. III Kelurahan Balai Agung Kecamatan Sekayu. Waktu penelitian untuk memperoleh data dan informasi di lakukan selama 3 (tiga) bulan.

\subsection{Desain Penelitian}

Desain penelitian merupakan rancangan bagaimana suatu penelitian akan dilakukan. Dimana rancangan tersebut digunakan untuk mendapatkan jawaban mengenai pertanyaan penelitian yang dirumuskan, yaitu penelitian tentang pengaruh gaya kepemimpinan dan disiplin kerja yang telah diterapkan oleh Lurah Kelurahan Balai Agung.

\subsection{Jenis dan Sumber Data}

Jenis data yang digunakan dalam penelitian ini adalah data kuantitatif, yaitu data atau informasi yang didapatkan dalam bentuk angka yang kemudian di proses menggunakan rumus matematika atau dapat juga di analisis dengan sistem statistik.

Adapun sumber data dalam penelitian ini merupakan data primer. Menurut Husein (2015:45)Data primer adalah data yang diperoleh langsung dari sumber asli (tidak melalui media perantara) data primer dapat berupa opini subjek (orang) secara individual atau kelompok, hasil observasi terhadap suatu benda atau fisik, kejadian atau kegiatan, dan hasil pengujian. Adapun data yang digunakan peneliti berupa data hasil wawancara dan jawaban kuisioner dari pegawai Kelurahan Balai Agung. 


\subsection{Teknik Pengumpulan Data}

Adapun teknik pengumpulan data yang digunakan dalam penelitian ini yaitu dengan cara observasi dan pembagian kuisioner. Observasi dilakukan dengan cara peneliti mengobservasi langsung subjek dan tempat penelitian. Kemudian dalam melakukan penelitian peneliti membagikan kuisioner yang berisi pertanyaan dengan skala yang telah ditentukan kepada sampel penelitian sebanyak 45 orang.

\subsection{Operasional Variabel Penelitian}

\begin{tabular}{|c|c|c|c|c|}
\hline Variabel & Definisi Variabel & Indikator & $\begin{array}{c}\text { Nomor } \\
\text { Pertanyaan }\end{array}$ & $\begin{array}{c}\text { Skala } \\
\text { Pengukuran }\end{array}$ \\
\hline Gaya Kepemimpinan (X) & $\begin{array}{l}\text { Kartono(2008:213)meny } \\
\text { atakan kepemimpinan } \\
\text { merupakan seorang } \\
\text { pribadi yang memiliki } \\
\text { superioritas tertentu, } \\
\text { sehingga ia memiliki } \\
\text { kewajiban dan kekuasaan } \\
\text { untuk menggerakkan } \\
\text { orang lain melakukan } \\
\text { usaha bersama guna } \\
\text { mencapai suatu tujuan } \\
\text { tertentu. }\end{array}$ & $\begin{array}{l}\text { 1. Kemampuan } \\
\text { Mengambil } \\
\text { Keputusan } \\
\text { 2. Kemampuan } \\
\text { Memotivasi } \\
\text { 3. Kemampuan } \\
\text { Komunikasi } \\
\text { 4. Kemampuan } \\
\text { Mengendalikan } \\
\text { Bawahan } \\
\text { 5. Kemampuan } \\
\text { Tanggung Jawab } \\
\text { 6. Kemampuan } \\
\text { Mengendalikan } \\
\text { Emosional }\end{array}$ & $\begin{array}{l}3 \\
4 \\
5 \\
6 \\
7\end{array}$ & Likert \\
\hline Disiplin Kerja (Y) & 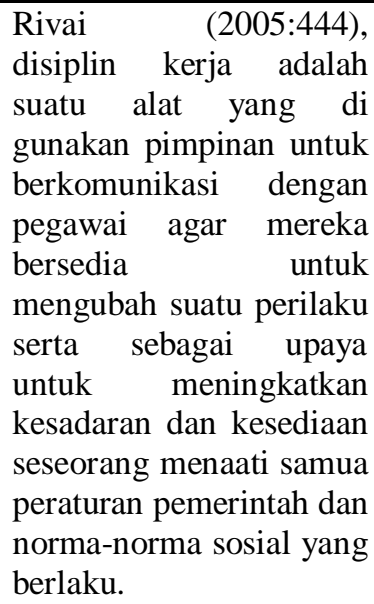 & $\begin{array}{l}\text { 1. Kehadiran } \\
\text { 2. Ketaatan kepada } \\
\text { peraturan kerja } \\
\text { 3. Ketaatan pada } \\
\text { standar kerja } \\
\text { 4. tingkat } \\
\text { kewaspadaan } \\
\text { tinggi } \\
\text { 5. Bekerja etis }\end{array}$ & $\begin{array}{c}4 \\
5 \\
6-7\end{array}$ & Likert \\
\hline
\end{tabular}

\subsection{Instrumen Penelitian}

Instrumen dalam penelitian ini berupa kuesioner yang berkaitan dengan variabel-variabel yang digunakan berupa variabel bebas, yaitu Gaya Kepemimpinan (X), serta variabel terikat yaitu Disiplin Kerja (Y). Kuesioner yang dibuat, menggunakan kuesioner tertutup, yaitu responden hanya menjawab sesuai dengan persepsi mereka menurut skala yang digunakan, yaitu skala likert.

Priyatno (2012: 16), menyatakan teknik pengajuan instrumen dalam penelitian adalah sebagai berikut:

\subsubsection{Uji Validitas}

Validitas berarti mempunyai tingkat-tingkat kevalidan atau kesahihan dari suatu instrumen. Artinya disini kita ingin melihat apakah instrumen yang kita buat valid untuk 
digunakan. Adapun anlisis data untuk mengetahui tingkat kevalidan instrumen dilakukan menggunakan software SPSS dengan ketentuan berikut:

$\mathrm{R}$ Hitung $>\mathrm{R}$ Tabel $=$ instrumen valid

$\mathrm{R}$ Hitung $<\mathrm{R}$ Tabel $=$ instrumen tidak valid (Sugiyono, 2017).

\subsubsection{Uji Reliabilitas}

Relibialitas menunjuk pengertian bahwa instrumen tersebut dapat dipercaya. Adapun analisis data untuk mengetahui relibialitas dilakukan dengan software SPSS dengan ketentuan semakin kecil nilai alpha yang diperoleh. Adapun analisis data untuk mengetahui relibialitas dilakukan dengan software SPSS dengan ketentuan semakin kecil nilai alpha yang diperoleh maka semakin banyak item yang tidak reliabel. Standar yang digunakan adalah alpha $>0,70$.

\subsection{Populasi dan Sampel}

Adapun yang menjadi populasi dalam penelitian ini adalah pegawai yang bekerja di Kelurahan Balai Agung sebanyak 45 orang. Perhitungan jumlah sampel dari 45 orang adalah sebagai berikut:

$$
\begin{aligned}
& n=\frac{N}{N(d)^{2}+1} \\
& n=\frac{45}{45(0,05)^{2}+1} \\
& n=\frac{45}{45(0,0025)+1} \\
& n=\frac{45}{0,1125+1} \\
& n=\frac{45}{1,1125} \\
& n=40,449 \\
& n=40
\end{aligned}
$$

Jadi sampel yang digunakan dalam penelitian ini adalah 40 sampel.

\subsection{Teknik Analisis Data}

Pada penelitian ini, Penulis menggunakan teknik analisis kuantitatif. Adapun teknik analisis kuantitatif yang digunakan Penulis pada penelitian ini adalah dengan melakukan pengujian hipotesis. Pengujian ini digunakan untuk mengetahui apakah variabel independen mempengaruhi secara signifikan terhadap variabel dependen.

\subsubsection{Analisis Regresi Linier Sederhana}

Analisis ini digunakan untuk mengetahui seberapa besar pengaruh variabel bebas yaitu:

gaya kepemimpinan (X) terhadap disiplin kerja (Y). Sunyoto (2013: 110), menyatakan persamaan regresi linier sederhana adalah sebagai berikut:

$\mathrm{Y}=\mathrm{a}+\mathrm{Bx}+\mathrm{e}$

Keterangan :

$\mathrm{Y}=$ Variabel dependen (disiplin kerja)

$\mathrm{a}=$ Konstanta

$\mathrm{b}=$ Koefisien garis regresi

$\mathrm{X}=$ Gaya kepemimpinan

\subsection{Pengujian Hipotesis}

1. Uji Korelasi (R)

\begin{tabular}{|c|c|}
\hline Koefisien Korelasi & Kriteria \\
\hline $0,00-0,199$ & Sangat Rendah \\
$0,20-0,399$ & Rendah \\
$0,40-0,599$ & Sedang \\
\hline
\end{tabular}




\begin{tabular}{|c|c|}
\hline $0,60-0,799$ & Kuat \\
$0,80-1,000$ & Sangat Kuat \\
\hline
\end{tabular}

Sumber: Sugiyono (2012: 78)

2. Koefisien Determinasi $\left(R^{2}\right)$

Kuncoro (2008: 220), menyatakan koefisien determinasi mengukur seberapa jauh kemampuan model dalam menerangkan variasi variabel dependennya. Nilai koefisien determinasi adalah antara nol dan satu nilai $\mathrm{R}^{2}$ yang kecil berarti kemampuan variabel-variabel indenpendent dalam menjelaskan variasi variabel dependen sangat terbatas dan nilai yang mendekati satu berarti variabel-variabel independen memberikan hampir semua informasi yang dibutuhkan untuk memprediksi variasi variabel dependentnya.

3. Uji Signifikasi Pengaruh Parsial (Uji t)

Uji t digunakan untuk menguji signifikasi hubungan antara variabel $\mathrm{X}$ dan $\mathrm{Y}$, apakah variabel $\mathrm{X}$ (gaya kepemimpinan) benar-benar berpengaruh terhadap variabel $\mathrm{Y}$ (disiplin kerja) secara terpisah atau parsial Priyatno (2009: 61).

Hipotesis yang digunakan dalam pengujian ini adalah:

Ho : Gaya kepemimpinan tidak berpengaruh terhadap disiplin kerja pegawai pada Kelurahan Balai Agung Kecamatan Sekayu Kabupaten Musi Banyuasin.

Ha : Gaya kepemimpinan berpengaruh terhadap disiplin kerja pegawai pada Kelurahan Balai Agung Kecamatan Sekayu Kabupaten Musi Banyuasin.

Dasar pengambilan keputusan Priyatno (2009: 63), adalah dengan menggunakan angka probabilitas signifikansi yaitu:

a. Apabila t hitung < t tabel, maka Ho diterima dan Ha ditolak.

b. Apabila t hitung $>\mathrm{t}$ tabel, maka Ho diterima dan Ha ditolak.

\subsection{Konsep Gaya Kepemimpinan \\ 2.1.1 Pengertian Kepemimpinan}

Kepemimpinan menurut Hasibuan (2011:167). Pemimpin adalah seseorang yang mempergunakan wewenang dan kepemimpinannya untuk mengarahkan orang lain serta bertanggung jawab atas pekerjaannya untuk mencapai suatu tujuan. Menurut Kartini Kartono (2010:120). Pemimpin adalah seorang pribadi yang memiliki kecakapan dan kelebihan, khususnya kecakapan dan kelebihan disuatu bidang sehingga dia mampu mempengaruhi orang lain untuk bersama-sama melakukan aktivitas-aktivitas tertentu demi pencapaian suatu atau beberapa tujuan.

\subsubsection{Gaya Kepemimpinan}

Menurut Thoha (2010: 49) mengemukakan bahwa gaya kepemimpinan merupakan norma perilaku yang digunakan oleh seseorang pada saat orang tersebut mencoba mempengaruhi perilaku orang lain atau bawahan.

\subsubsection{Jenis-jenis Gaya Kepemimpinan}

Menurut Hasibuan (2016:172). Gaya kepemimpinan dibagi menjadi 3 (tiga) yaitu sebagai berikut:

a. Kepemimpinan Otoriter

Kepemimpinan otoriter adalah jika kekuasaan atau wewenang, sebagian besar mutlak tetap berada pada pimpinan atau kalau pimpinan itu menganut system sentralisasi wewenang. Pengambilan keputusan dan kebijaksanaan hanya ditetapkan sendiri oleh pemimpin, bawahan tidak diikutsertakan untuk memberikan saran, ide dan pertimbangan dalam proses pengambilan keputusan. 
Orientasi kepemimpinannya difokusnya hanya untuk meningkatkan produktivitas kerja karyawan dengan kurang memperhatikan perasaan dan kesejahteraan bawahan. Pimpinan menganut sistem manajemen tertutup (closed management), kurang menginformasikan keadaan perusahaan pada bawahannya. Pengkaderan kurang mendapat perhatiannya.

b. Kepemimpinan Partisipatif

Kepemimpinan partisipatif adalah apabila dalam kepemimpinannya dilakukan dengan cara persuasif, menciptakan kerjasama yang serasi, menumbuhkan dan partisipasi para bawahannya. Pemimpin memotivasi bawahan agar merasa ikut memiliki perusahaan.

Pemimpin dengan gaya partisipasif akan mendorong kemampuan bawahan mengambil keputusan. Dengan demikian, pimpinan akan selalu membina bawahan untuk menerima tanggung jawab yang lebih besar.

c. Kepemimpinan Delegatif

Kepemimpinan delegatif bila seorang pemimpin mendelegasikan wewenang kepada bawahan dengan agak lengkap. Dengan demikian, bawahan dapat mengambil keputusan dan kebijaksanaan dengan bebas atau leluasa dalam mengerjakan pekerjaannya. Pemimpin tidak peduli cara bawahan mengambil keputusan dan mengerjakan pekerjaannya, sepenuhnya diserahkan kepada bawahannya itu.

Dalam hal ini, bawahan dituntut memiliki kematangan pekerjaan (kemampuan) dan kematangan psikologis (kemauan).

\subsubsection{Tipe Gaya Kepemimpinan}

Sedangkan menurut Sutikno (2014: 35), gaya kepemimpinan terbagi menjadi beberapa tipe, yaitu:

a. Tipe Otokratik

Tipe kepemimpinan menganggap bahwa kepemimpinan adalah hak pribadinya (pemimpin), sehingga ia tidak perlu berkonsultasi dengan orang lain dan tidak boleh ada orang lain yang turut campur. Seorang pemimpin otokratik akan menunjukkan sikap yang menonjolkan keakuannya, dan selalu mengabaikan peranan bawahan dalam proses pengambilan keputusan, tidak mau menerima saran dan pandangan bawahannya.

b. Tipe Kendali Bebas atau Masa Bodo (Laisez Faire)

Tipe kepemimpinan ini merupakan kebalikan dari tipe kepemimpinan otokratik. Dalam kepemimpinan tipe ini sang pemimpin biasanya menunjukkan perilaku yang pasif dan seringkali menghindar diri dari tanggung jawab. Seorang pemimpin yang kendali bebas cenderung memilih peran yang pasif dan membiarkan organisasi berjalan menurut temponya sendiri. Disini seorang pemimpin mempunyai keyakinan bebas dengan memberikan kebebasan yang seluas-luasnya terhadap bawahan maka semua usahanya akan cepat berhasil.

c. Tipe Paternalistik

Persepsi seorang pemimpin yang paternalistik tentang peranannya dalam kehidupan organisasi dapat dikatakan diwarnai oleh harapan bawahan kepadanya. Harapan bawahan berwujud keinginan agar pemimpin mampu berperan sebagai bapak yang bersifat melindungi dan layak dijadikan sebagai tempat bertanya dan untuk memperoleh petunjuk, memberikan perhatian terhadap kepentingan dan kesejahteraan bawahannya.

d. Tipe Kharismatik 
Seorang pemimpin yang kharismatik memiliki karakteristik khusus yaitu daya tariknya yang sangat memikat, sehingga mampu memperoleh pengikut yang sangat besar dan para pengikutnya tidak selalu dapat menjelaskan secara konkrit mengapa orang tersebut itu dikagumi.

e. Tipe Militeristik

Pemimpin yang bertipe militeristik ialah pemimpin dalam menggerakkan bawahannya lebih sering mempergunakan sistem perintah, senang bergantung kepada pangkat dan jabatannya, dan senang kepada formalitas yang berlebihlebihan. Menuntut disiplin yang tinggi dan kaku dari bawahannya, dan sukar menerima kritikan dari bawahannya.

f. Tipe Pseudo-demokratik

Pemimpin seperti ini menjadikan demokrasi sebagai selubung untuk memperoleh kemenangan tertentu. Pemimpin yang bertipe pseudo-demokratik hanya tampaknya saja bersikap demokratis padahal sebenarnya dia bersikap otokratis. Pemimpin ini menganut demokrasi semu dan lebih mengarah kepada kegiatan pemimpin yang otoriter dalam bentuk yang halus dan samar-samar.

g. Tipe Demokratik

Tipe demokratik adalah tipe pemimpin yang demokratis, dan bukan karena dipilihnya si pemimpin secara demokratis. Tipe kepemimpinan dimana pemimpin selalu bersedia menerima dan menghargai saran-saran, pendapat, dan nasihat dari staf dan bawahan, melalui forum musyawarah untuk mencapai kata sepakat. Kepemimpinan demokratik adalah kepemimpinan yang aktif, dinamis, dan terarah. Kegiatan-kegiatan pengendalian dilaksanakan secara tertib dan bertanggung jawab.

\subsubsection{Indikator Gaya Kepemimpinan}

Menurut Kartono (2008: 213), gaya kepemimpinan seseorang dapat dilihat dan dinilai dari beberapa indikator sebagai berikut:

1. Kemampuan Mengambil Keputusan. Pengambilan keputusan adalah suatu pendekatan yang sistematis terhadap hakikat alternatif yang dihadapi dan mengambil tindakan yang menurut perhitungan merupakan tindakan yang paling tepat.

2. Kemampuan Memotivasi. Kemampuan Memotivasi adalah Daya pendorong yang mengakibatkan seorang anggota organisasi mau dan rela untuk menggerakkan kemampuannya (dalam bentuk keahlian atau keterampilan) tenaga dan waktunya untuk menyelenggarakan berbagai kegiatan yang menjadi tanggung jawabnya dan menunaikan kewajibannya, dalam rangka pencapaian tujuan dan berbagai sasaran organisasi yang telah ditentukan sebelumnya.

3. Kemampuan Komunikasi. Kemampuan Komunikasi Adalah kecakapan atau kesanggupan penyampaian pesan, gagasan, atau pikiran kepada orang lain dengan tujuan orang lain tersebut memahami apa yang dimaksudkan dengan baik, secara langsung lisan atau tidak langsung.

4. Kemampuan Mengendalikan Bawahan. Seorang Pemimpin harus memiliki keinginan untuk membuat orang lain mengikuti keinginannya dengan menggunakan kekuatan pribadi atau kekuasaan jabatan secara efektif dan pada tempatnya demi kepentingan jangka panjang perusahaan. Termasuk di dalamnya memberitahukan orang lain apa yang harus dilakukan dengan nada yang bervariasi mulai dari nada tegas sampai meminta atau bahkan mengancam. Tujuannya adalah agar tugas-tugas dapat terselesaikan dengan baik.

5. Tanggung Jawab. Seorang pemimpin harus memiliki tanggung jawab kepada 
bawahannya. Tanggung jawab bisa diartikan sebagai kewajiban yang wajib menanggung, memikul jawab, menanggung segala sesuatunya atau memberikan jawab dan menanggung akibatnya.

6. Kemampuan Mengendalikan Emosional. Kemampuan Mengendalikan Emosional adalah hal yang sangat penting bagi keberhasilan hidup kita. Semakin baik kemampuan kita mengendalikan emosi semakin mudah kita akan meraih kebahagiaan.

\subsection{Disiplin Kerja}

\subsubsection{Pengertian Disiplin Kerja}

Menurut Rivai (2005:444), Disiplin kerja adalah suatu alat yang di gunakan pemimpin untuk berkomunikasi dengan pegawai agar mereka bersedia untuk mengubah suatu perilaku serta sebagai upaya untuk meningkatkan kesadaran dan kesediaan seseorang dalam menaati semua peraturan pemerintah dan norma-norma sosial yang beerlaku.

\subsubsection{Bentuk-Bentuk Disiplin Kerja}

Menurut Mangkunegara (2011:129), ada dua (2) bentuk-bentuk disiplin kerja yaitu :

1. Disiplin Preventif aadalah upaya untuk mengerakkan pegawai mengikuti dan mematuhi peraturan kerja pada instansi pemerintahan. Tujuan dasarnya adalah untuk mengerakkan pegawai beerdisiplin diri. Dengan cara preventif, pegawai dapat memelihara dirinya terhadap peraturan-peraturan di dalam instansi pemerintahan.

2. Disiplin Korektif adalah upaya mengerakkan pegawai dalam suatu peraturan dan mengarahkan untuk tetap mematuhi peraturan sesuai dengan pedoman pada instansi pemerintahan.

\subsubsection{Indikator Disiplin Kerja} berikut:

Menurut Rivai (2005:444), indikator-indikator disiplin kerja yaitu sebagai

1. Kehadiran

Hal ini menjadi indikator yang mendasar untuk mengukur kedisiplinan dan biasanya pegawai yang memiliki disiplin rendah terbiasa untuk terlambat bekerja.

2. Ketaatan pada peraturan keja

Pegawai yang taat kepada peraturan kerja tidak akan melalaikan prosedur kerja dan akan selalu mengikuti pedoman kerja yang di tetapkan oleh pemerintah.

3. Ketaatan pada standar kerja

Hal ini dapat dilihat melalui besarnya tanggung jawab pegawai yang di amanahkan kepadanya.

4. Tingkat kewaspadaan tinggi

Pegawai yang memiliki tingkat kewaspadaan tinggi akan selalu berhati-berhati, penuh perhitungan dan selalu menggunakan ketelitian dalam bekerja secara efektif dan efisien.

5. Bekerja etis

Beberapa pegawai mungkin melakukan tindakan yang tidak sopan terhadap pelayanan atau terlibat dalam tindakan yang tidak pantas. Hal ini merupakan salah satu wujud dari tidak disiplin kerja pegawai.

\subsubsection{Faktor-Faktor yang Mempengaruhi Disiplin Kerja}


Menurut Henry (2012:142), bahwa faktor-faktor yang mempengaruhi disiplin kerja sebagai berikut:

1. Faktor kepribadian

Faktor yang penting dalam kepribadian seseorang adlah sistem nilai yang dianut. Sistem nilai dalam hal ini yang berkaitan langsung dengan disiplin. Nilai-nilai yang menjunjung disiplin yang timbul dari diri yang di gunakan sebagai kerangka acuan bagi penerapan disiplin ditempat kerja. sistem nilai akan terlihat dari sikap seseorang.

2. Faktor lingkungan

Faktor yang penting yang berasal dari lingkungan baik eksternal maupun internal, yang di terapkan di dalam suatu lingkungan organisasi maupun lingkungan instansi/perusahaan yang berdasarka atas disiplin sikap dari sistem nilai seseorang.

\subsubsection{Hubungan Gaya Kepemimpinan Terhadap Disiplin Kerja}

Menurut Thoha (2010:42). Dengan menggunakan kepemimpinan maka pemimpin akan mempengaruhi persepsi bawahan dan motivasinya, dengan cara mengarahkan pegawai pada kejelasan tugas, pencapaian, tujuan, kepuasan kerja, dan pelaksanaan kerja yang efektif. Menurut Robbins (2007:432). Kepemimpinan sebagai kemampuan untuk mempengaruhi suatu kelompok menuju pencapaian sasaran.

2.2.6 Penelitian Terdahulu

\begin{tabular}{|c|c|c|c|c|c|}
\hline No & Judul Penelitian & $\begin{array}{l}\text { Variabel } \\
\text { Penelitian }\end{array}$ & $\begin{array}{l}\text { Metodologi } \\
\text { Penelitian }\end{array}$ & $\begin{array}{c}\text { Hasil } \\
\text { Penelitian }\end{array}$ & $\begin{array}{l}\text { Perbedaan } \\
\text { Penelitian }\end{array}$ \\
\hline 1. & $\begin{array}{l}\text { Pengaruh Gaya } \\
\text { Kepemimpinan } \\
\text { Terhadap Kinerja } \\
\text { Karyawan Pada Cha- } \\
\text { Cha Resto Dan } \\
\text { Karaoke Keluarga } \\
\text { Sekayu } \\
\text { (Herlinda, 2011) }\end{array}$ & $\begin{array}{l}\text { Gaya } \\
\text { Kepemimpinan } \\
(\mathrm{X}) \\
\text { Kinerja } \\
\text { Karyawan (Y) }\end{array}$ & $\begin{array}{l}\text { Metode } \\
\text { Kuantitatif }\end{array}$ & $\begin{array}{l}\text { Gaya } \\
\text { Kepemimpina } \\
\text { n Berpengaruh } \\
\text { Secara } \\
\text { Signifikan } \\
\text { Terhadap } \\
\text { Kinerja } \\
\text { Pegawai }\end{array}$ & $\begin{array}{lr}\text { Pada } & \text { Judul, } \\
\text { Objek, Sampel } \\
\text { Dalam } \\
\text { Penelitian }\end{array}$ \\
\hline 2. & $\begin{array}{l}\text { Pengaruh Gaya } \\
\text { Kepemimpinan } \\
\text { Terhadap Kinerja } \\
\text { Karyawan Pada PT. } \\
\text { Muba link Kabupaten } \\
\text { Musi Banyuasin } \\
\text { (Taufik, 2013) }\end{array}$ & $\begin{array}{l}\text { Gaya } \\
\text { Kepemimpinan } \\
(\mathrm{X}) \\
\text { Kinerja } \\
\text { Karyawan (Y) }\end{array}$ & $\begin{array}{l}\text { Metode } \\
\text { Kuantitatif }\end{array}$ & $\begin{array}{l}\text { Gaya } \\
\text { Kepemimpina } \\
\text { n Berpengaruh } \\
\text { Secara } \\
\text { Signifikan } \\
\text { Terhadap } \\
\text { Kinerja } \\
\text { Pegawai }\end{array}$ & $\begin{array}{lr}\text { Pada } & \text { Judul, } \\
\text { Objek, Sampel } \\
\text { Dalam } \\
\text { Penelitian }\end{array}$ \\
\hline
\end{tabular}




\subsection{Kerangka Pemikiran}

\begin{tabular}{|l|}
\hline \multicolumn{1}{|c|}{ Gaya Kepemimpinan (X) } \\
\hline 1. Kemampuan Mengambil \\
Keputusan \\
2. Kemampuan Memotivasi \\
3. Kemampuan Komunikasi \\
4. Kemampuan Mengendalikan \\
$\quad$ Bawahan \\
5. Kemampuan Tanggung Jawab \\
6. Kemampuan Mengendalikan \\
$\quad$ Emosional \\
Sumber: Kartono (2008: 213) \\
\hline
\end{tabular}

\begin{tabular}{|l|}
\hline \multicolumn{2}{|c|}{ Disiplin Kerja (Y) } \\
\hline 1. Kehadiran \\
2. Ketaatan Kepada Peraturan \\
Kerja \\
3. Ketaatan Pada Standar Kerja \\
4. Tingkat Kewaspadaan Tinggi \\
5. Bekerja Etis \\
Sumber: Rivai (2005: 444) \\
\hline
\end{tabular}

\subsection{Hipotesis}

Berdasarkan latar belakang permasalahan yang telah penulis uraikan diatas, maka hipotesis dalam penelitian ini adanya pengaruh gaya kepemimpinan terhadap disiplin kerja pegawai pada Kelurahan Balai Agung Kecamatan Sekayu Kabupaten Musi Banyuasin.

\subsection{Uji Validitas}

\begin{tabular}{|c|c|c|c|c|}
\hline \multicolumn{2}{|c}{ Hasil Uji Validitas Item Variabel Gaya Kepemimpinan (X) } \\
\hline No Item & Pearsion correlation & Sig (2-Tailed) & $r_{\text {tabel }}$ & Keterangan \\
\hline Item1 & 0.842 & 0.000 & 0,3120 & Valid \\
\hline Item2 & 0.809 & 0.000 & 0,3120 & Valid \\
\hline Item3 & 0.857 & 0.000 & 0,3120 & Valid \\
\hline Item4 & 0.648 & 0.000 & 0,3120 & Valid \\
\hline Item5 & 0.711 & 0.000 & 0,3120 & Valid \\
\hline Item6 & 0.850 & 0.000 & 0,3120 & Valid \\
\hline Item7 & 0.727 & 0.000 & 0,3120 & Valid \\
\hline
\end{tabular}

Sumber: Data Primer (diolah) Th.2021

Hasil Uji Validitas Item Variabel Disiplin Kerja(Y)

\begin{tabular}{|c|c|c|c|c|}
\hline No Item & Pearsion correlation & Sig (2-Tailed) & $r_{\text {tabel }}$ & Keterangan \\
\hline Item1 & 0.777 & 0.000 & 0,3120 & Valid \\
\hline Item2 & 0.752 & 0.000 & 0,3120 & Valid \\
\hline Item3 & 0.597 & 0.000 & 0,3120 & Valid \\
\hline
\end{tabular}


JURNAL MANAJEMEN KOMPETEN

Vol. 4 No.1 Juli 2021, 72-86

\begin{tabular}{|c|c|c|c|c|}
\hline Item4 & 0.670 & 0.000 & 0,3120 & Valid \\
\hline Item5 & 0.665 & 0.000 & 0,3120 & Valid \\
\hline Item6 & 0.614 & 0.000 & 0,3120 & Valid \\
\hline Item7 & 0.777 & 0.000 & 0,3120 & Valid \\
\hline
\end{tabular}

Sumber: Data Primer (diolah) Th.2021

\subsection{Uji Realibilitas}

\begin{tabular}{|c|c|l|}
\hline Variabel & Cronbach's Alpa & Keterangan \\
\hline Gaya Kepemimpinan (X) & 0.890 & Reliabilitas \\
\hline Disiplin Kerja (Y) & 0.821 & Reliabilitas \\
\hline
\end{tabular}

Sumber: Data Primer (diolah) Th.2021

\subsection{Teknik Analisis Data}

\subsubsection{Analisis Regresi Linier Sederhana}

\section{Hasil Pengujian Regresi Linier sederhana}

Coefficients $^{a}$

\begin{tabular}{|c|c|c|c|c|c|}
\hline \multirow[t]{2}{*}{ Model } & \multicolumn{2}{|c|}{$\begin{array}{l}\text { Unstandardized } \\
\text { Coefficients }\end{array}$} & $\begin{array}{c}\text { Standardize } \\
\mathrm{d}\end{array}$ & $\mathrm{T}$ & Sig. \\
\hline & B & Std. Error & Beta & & \\
\hline (Constant) & 8.542 & 3.653 & & 2.338 & .025 \\
\hline $\begin{array}{l}\text { gaya } \\
\text { kepemimpinan }\end{array}$ & .734 & .115 & .718 & 6.365 & .000 \\
\hline
\end{tabular}

a. Dependent Variable: disiplin kerja

sumber: Data Primer (diolah) Th.2021

$\mathbf{Y}=\mathbf{a}+\mathbf{b X}$

$\mathrm{Y}=8.542+0.734 \mathrm{X}$

Dari persamaan regresi diatas dapat dijelaskan bahwa:

a. Nilai konstanta sebesar 8.542, menyatakan bahwa besarnya nilai variabel Y jika variabel bebasnya dianggap nol artinya tanpa dipengaruhi variabel gaya kepemimpinan (X) maka besarnya variabel disiplin kerja (Y) pegawai pada Kelurahan Balai Agung Kecamatan Sekayu Kabupaten Musi Banyuasin adalah tetap sebesar 8.542.

b. Koefisien regresi yaitu gaya kepemimpinan (X) memiliki koefisien positif sebesar 0,734 dengan nilai signifikan $0,000<\alpha 5 \%(0,05)$, yang artinya variabel gaya kepemimpinan $(\mathrm{X})$ berpengaruh positif dan signifikan terhadap variabel disiplin kerja (Y). Maka setiap peningkatan (penambahan) variabel gaya kepemimpinan (X) akan meningkatkan variabel disiplin kerja (Y) sebesar 0,734. Dengan asumsi variabel lain dianggap konstanta. 


\subsubsection{Uji Korelasi}

Model Summary

\begin{tabular}{|l|r|r|r|c|}
\hline Model & \multicolumn{1}{|c|}{$\mathrm{R}$} & R Square & \multicolumn{1}{|c|}{$\begin{array}{c}\text { Adjusted R } \\
\text { Square }\end{array}$} & $\begin{array}{c}\text { Std. Error of the } \\
\text { Estimate }\end{array}$ \\
\hline 1 & $.718^{\mathrm{a}}$ & .516 & .503 & 2.353 \\
\hline
\end{tabular}

a. Predictors: (Constant), gaya kepemimpinan

sumber: Data Primer (diolah) Th.2021

\subsubsection{Uji hipotesis}

\begin{tabular}{|c|c|c|c|c|c|c|}
\hline \multicolumn{7}{|c|}{ Coefficients $^{a}$} \\
\hline \multirow{2}{*}{\multicolumn{2}{|c|}{ Model }} & \multicolumn{2}{|c|}{ Unstandardized Coefficients } & Standardized & \multirow[t]{2}{*}{$\mathrm{T}$} & \multirow[t]{2}{*}{ Sig. } \\
\hline & & $\mathrm{B}$ & Std. Error & Beta & & \\
\hline & (Constant) & 8.542 & 3.653 & & 2.338 & .025 \\
\hline 1 & $\begin{array}{l}\text { gaya } \\
\text { kepemimpinan }\end{array}$ & .734 & .115 & .718 & 6.365 & .000 \\
\hline
\end{tabular}

a. Dependent Variable: disiplin kerja

sumber: Data Primer (diolah) Th.2021

\subsubsection{Analisis koefisien determinasi}

Model Summary

\begin{tabular}{|l|r|r|r|r|}
\hline $\begin{array}{l}\text { Mode } \\
1\end{array}$ & \multicolumn{1}{|c|}{$\mathrm{R}$} & R Square & \multicolumn{1}{c|}{$\begin{array}{c}\text { Adjusted R } \\
\text { Square }\end{array}$} & $\begin{array}{l}\text { Std. Error of the } \\
\text { Estimate }\end{array}$ \\
\hline 1 & $.718^{\mathrm{a}}$ & .516 & .503 & 2.353 \\
\hline
\end{tabular}

a. Predictors: (Constant), gaya kepemimpinan

sumber: Data Primer (diolah) Th.2021

\subsection{Pembahasan}

Hasil penelitian yang dilakukan terhadap Variabel (X) dan Variabel (Y) menunjukkan bahwa terdapat pengaruh gaya kepemimpinan terhadap disiplin kerja. Hal ini dibuktikan dengan hasil analisis menggunakan regresi linier sederhana dengan hasil $\mathrm{Y}=\mathrm{a}+\mathrm{bx} \mathrm{Y}=8.542+0.734 \mathrm{X}$ yang telah dilakukan menggunakan aplikasi SPSS 20 . Analisis dilakukan terhadap 40 orang responden

berjenis kelamin laki-laki sebanyak 21 orang pegawai dan yang berjenis kelamin perempuan sebanyak 16 orang pegawai.

\subsection{Implementasi Hasil Penelitian}

Dari hasil analisis data yang dilakukan diatas didapat hasil bahwa gaya kepemimpinan $(\mathrm{X})$ berpengaruh secara signifikan terhadap disiplin kerja $(\mathrm{Y})$ karena memiliki nilai $t_{\text {hitung }}>t_{\text {tabel }}$. Hal ini dibuktikan dari nilai $t_{\text {hitung }}$ sebesar $6.365>$ $\mathrm{t}_{\text {tabel }} 1.68385$. Sesuai dengan rentang interprestasi koefisien korelasi yang berada antara 0.60-0.799, maka dapat dinyatakan bahwa gaya kepemimpinan (X) memiliki pengaruh terhadap disiplin kerja (Y) pegawai pada Kelurahan Balai Agung Kecamatan Sekayu Kabupaten Musi Banyuasin.Hal ini mendukung penelitian terdahulu yang dilakukan oleh Herlinda dengan judul "Pengaruh Gaya Kepemimpinan Terhadap Kinerja Karyawan Pada Cha-Cha Resto Dan Karaoke Keluarga Sekayu" yang menyatakan bahwa terdapat pengaruh gaya kepemimpinan terhadap kinerja pegawai. 


\subsection{Kesimpulan}

Berdasarkan dari pembahasan maka dapat disimpulkan bahwa:

1. Dari hasil penelitian analisis data korelasi yang dilakukan diatas dinyatakan bahwa hasil gaya kepemimpinan $(\mathrm{X})$, mempunyai hubungan yang kuat terhadap disiplin kerja (Y) dan mempunyai nilai korelasi R sebesar 0.718 .

2. Dari hasil analisis uji hipotesis $\mathrm{t}$, gaya kepemimpinan $(\mathrm{X})$ berpengaruh secara signifikan terhadap disiplin kerja (Y), karena memiliki nilai thitung sebesar $6.365>$ nilai $t_{\text {tabel }}$ sebesar 1.68385, dan didukung nilai signifikan $0,000<\alpha 5 \%(0,05)$.

3. Berdasarkan hasil analisis regresi linier sederhana didapat persamaan sebagai berikut $\mathrm{Y}=8.542+0.734 \mathrm{X}$ dimana nilai konstanta sebesar 8.542 menunjukkan apabila variabel gaya kepemimpinan (X) nilainya adalah 0 , maka besarnya nilai disiplin kerja (Y)sebesar 8.542. Koefisien regresi untuk variabel gaya kepemimpinan $(\mathrm{X})$ sebesar 0,734 . Tanda positif menunjukkan terjadinya perubahan yang searah dari variabel gaya kepemimpinan $(\mathrm{X})$ terhadap variabel disiplin kerja (Y).

4. Dari hasil uji determinasi, dapat dilihat nilai $\mathrm{R}$ square atau koefisien determinasi adalah 0,516 atau $51.6 \%$. ini menunjukan bahwa persentase sumbangan pengaruh variablel independen (gaya kepemimpinan) terhadap variabel dependen (disiplin kerja) sebesar $51.6 \%$. sedangkan sisanya sebesar $48.4 \%$ dipengaruhi oleh variabel lain yang tidak dibahas dalam penelitian ini.

\subsection{Saran}

Berdasarkan kesimpulan yang telah dilakukan maka saran yang dapat diberikan dalam penelitian ini yaitu :

1. Kelurahan Balai Agung

Bagi pemimpin hendaknya dengan diketahui bahwa kepemimpinan mempunyai pengaruh yang signifikan terhadap disiplin kerja pada Kelurahan Balai Agung Kecamatan Sekayu Kabupaten Musi Banyuasin, maka disarankan agar pemimpin menggunakan gaya kepemimpinan demokratik sehingga bisa meningkatkan disiplin kerja dan memberikan sanksi kepada pegawai yang melanggar aturan.

2. Peneliti Selanjutnya

Bagi peneliti selanjutnya penelitian ini dapat dijadikan sebagai bahan informasi dan refrensi untuk menambah ilmu pengetahuan bagi pihak-pihak yang berkepentingan. Serta dapat menganalisis variabel lain yang berkaitan dengan $\mathrm{X}$ dan $\mathrm{Y}$.

\section{DAFTAR PUSTAKA}

Arikunto, Suharsimi. 2010. Prosedur Penelitian Suatu Pendekatan Praktik. Yogyakarta : Rineka Cipta

Danang, Sunyoto. 2013. Metodologi Penelitian Akuntansi. Bandung: PT Refika Aditama Anggota Ikapi.

Hasibuan, S.P. Malayu. 2016. Manajemen Sumber Daya Manusia. Jakarta: PT. Bumi Aksara.

Henry, Simamora, 2012. Manajemen Sumber Daya Manusia. Edisi 1. Yogyakarta: STIE YKPN Yogyakarta.

Husein, Umar. 2014. Metodologi Penelitian Untuk Skripsi dan Tesis Bisnis. Jakarta: Rajawali

Iswara, 2013. Pengaruh Gaya Kepemimpinan, Budaya Organisasi dan Lingkungan Kerja Fisik Terhadap Disiplin Kerja Karyawan Pada Dinas Pertanian 
Tanaman Pangan dan Hortikultura Kota Denpasar. Jurnal Manajemen Universitas Udayana, Vol 2, no. 6, june 2013. ISSN 2302-8912.

Kartono, Kartini. 2010. Pemimpin dan Kepemimpinan. Jakarta: Raja Grafindo Persada.

Kuncoro Achmad, Engkus dan Riduwan. 2008. Cara Menggunakan dan Memakai Analisis Jalur. Bandung Alfabeta.

Mangkunegara, Anwar Prabu. 2011. Manajemen Sumber Daya Manusia. Bandung: PT. Remaja Rosda karya.

Moenir, H.A.S. 2010. Manajemen Pelayanan Umum di Indonesia. Jakarta: Bumi Aksara.

Notoatmodjo, S. 2012. Metodologi Penelitian Kesehatan. Jakarta: Rineka Cipta

Priyatno, Duwi. 2012. Cara Kilat Belajar Analisis Data dengan SPSS. Yogyakarta: Andi Offset.

Riduwan. 2005. Skala Pengukuran Variabel-variabel Penelitian. Bandung: Alfabeta.

Rivai, Veithzal. 2005. Performance Apprasial. Sistem Yang Tepat Untuk Menilai Karyawan dan Meningkatkan Daya Saing Perusahaan. Jakarta: Rajagrafindo Prasada.

Sedarmayanti, 2010. Sumber Daya Manusia dan Produktivitas Kerja, CV Mandar Maju, Bandung.

Sinungan, Muchdarsyah. 2010. Manajemen Sumber Daya Manusia. Jakarta: Bumi Aksara.

Sugiyono. 2013. Metode Penelitian Bisnis. Bandung: CV. Alfabeta.

Sutikno. 2014. Pemimpin dan Kepemimpinan: Tips Praktis untuk Menjadi Pemimpin yang di idolakan. Lombok: Holistika Lombok.

Thoha. 2010. Kepemimpinan dan Manajemen. Jakarta: PT. Raja Grafindo Persada. 